\title{
Understanding Creative Economy Concept through Innovation Adopters Perspective
}

\author{
Aulia Suminar Ayu ${ }^{1, a)}$ Prihatin Dwihantoro ${ }^{2)}$ I Gede Wyana Lokantara ${ }^{3)}$ \\ ${ }^{1}$ Universitas Selamat Sri, Kendal, Indonesia \\ a) author correspondence : aulia.suminar.a@gmail.com \\ ${ }^{2}$ Universitas Selamat Sri, Kendal, Indonesia \\ ${ }^{3}$ Universitas Selamat Sri, Kendal, Indonesia \\ DOl: https://doi.org/10.18196/ikm.121031
}

Article Info

Article history:

Received 5 Mar 2020

Revised 6 Apr 2020

Accepted 5 May 2020

\section{ABSTRACT}

This research is part of Creative Economy Sub-Sector's Mapping and Clustering in Kendal Regency. The research aims to describe stakeholder understanding (refers to Kendal Regency Government) towards the creative economy concept using diffusion of innovation theory. The diffusion of innovation is used because Kendal Regency Government is still not familiar with the concept of the creative economy. This qualitative descriptive research used interviews, observation, FGD, and literature study as the method to gather data. Results showed that from 229 SME labeled with the creative economy by Youth, Sports, and Tourism Department, Kendal Regency only 66 of them that met Creative Economy Agency (Badan Ekonomi Kreatif- BEKRAF) criteria. This means that the officials' understanding of the concept of the creative economy is not yet comprehensive. The creative economy is essential to shape the image of the regency (city branding). On the other hand, Kendal Regency had a program to improve the image of the city as a form of smart branding. Smart Branding was a derivation of the Smart City Kendal master plan in 2018-2028. The lack of relevant data in the Kendal District Government showed that the desire to improve the image of the city had not been worked out effectively.

Keywords: City Branding; Creative Economy; Diffusion of Innovation; SME

\section{ABSTRAK}

Penelitian ini merupakan bagian dari rangkaian penelitian pemetaan dan klasterisasi sub sektor ekonomi kreatif di Kabupaten Kendal. Tujuan dari penelitian ini adalah mendeskripsikan pemahaman stakeholder terkait, yakni Pemerintah Kabupaten Kendal akan konsep ekonomi kreatif menggunakan teori difusi inovasi. Difusi inovasi digunakan karena konsep ekonomi kreatif masih belum akrab di lingkungan Pemerintah Kabupaten Kendal. Tipe penelitian yang digunakan adalah kualitatif deskriptif, dengan metode pengumpulan data berupa wawancara, observasi, FGD, dan kajian literatur. Data sekunder berasal dari dokumen "Dinas Pemuda, Olahraga, dan Pariwisata, Kabupaten Kendal". Data diolah menggunakan teknik klasterisasi. Klasterisasi yang dilakukan berdasarkan kriteria subsektor ekonomi kreatif dan persebaran konsentrasi subsektor ekonomi kreatif. Hasil menunjukkan bahwa dari 229 UMKM dengan label 'ekonomi kreatif', hanya terdiri 66 UMKM Ekonomi Kreatif yang memenuhi kriteria Badan Ekonomi Kreatif (BEKRAF). Ini berarti pemahaman dinas terkait akan konsep ekonomi kreatif belum sepenuhnya komprehensif. Sedangkan saat FGD, dapat disimpulkan bahwa kurangnya 'kesadaran' akan pentingnya ekonomi kreatif. Ekonomi kreatif penting untuk membentuk wajah kabupaten (city branding). Di sisi lain, Kabupaten Kendal memiliki program memperbaiki wajah kota sebagai bentuk smart branding. Smart Branding merupakan turunan rencana dari master plan Smart City Kendal tahun 2018-2028. Minimnya data terkait di Pemerintah Kabupaten Kendal, menunjukan bahwa keinginan untuk memperbaiki wajah kota belum digarap secara efektif.

Kata Kunci: Branding Kota; Ekonomi Kreatif; Difusi Inovasi; UMKM 


\section{INTRODUCTION}

More than a decade ago, in 2006, the term creative economy was introduced to the broader public of Indonesia by President Susilo Bambang Yudhoyono. The president instructed the Department of Trade to burgeon the creative economy. Through the Department of Trade of Republic Indonesia, in 2007, Indonesia Design Power was established to study the creative economy. The 'Study of the Mapping of Creative Industry by Department of Trade 2007' found that the employment absorption in the creative industry accounted for 5,4 million workers with participation rate at 5,8\%. Indeed, export value resulted from the creative industry hit 81,4 billion rupiahs and contributed to national export value at $9,13 \%$. Concerning the Gross Domestic Product (GDP) of Indonesia, the amount of creative industry accounted for was 104,37 billion rupiahs. The fact above urged President Susilo Bambang Yudhoyono to impart distinctive care to the creative economy during his administration. In 2011, the creative economy, which was under the Ministry of Trade in the previous period, was bestowed an independent ministry, namely the Ministry of Tourism and Creative Economy, and Mari Elka Pangestu was appointed to be the minister responsible in 2014.

In the next period, the succession of leadership altered the form of the medium that coordinated the creative economy at the central government. Joko Widodo, as the President of the Republic of Indonesia 2014, placed the creative economy outside the ministry nomenclature by establishing the Creative Economy Agency (BEKRAF). This agency was lead by the head of BEKRAF, Triawan Munaf, from January 2015 to October 2019. The striking difference between the Ministry of Tourism and Creative Economy of the period 2011-2014 and the Creative Economy Agency of the period 2015-2019 lies on the subsectoral division within it. The new institution increased the number of creative economy subsectors to 16 from 14 by eliminating the subsector of 'Research and Development' and modifying design to Product Design, Interior Design, and Visual Communication Design.

Table 1. Differences in the 2014 and 2016 of the Creative Economy Subsector

\begin{tabular}{ll}
\multicolumn{1}{c}{ Creative Economy Subsector In 2014 } & \multicolumn{1}{c}{ Creative Economy Subsector In 2016} \\
\hline Architecture & Architecture \\
Design & Interior Design \\
& Visual Communication Design \\
& Product Design \\
Film, Video, Photography & Film, Animation, dan Video \\
& Photography \\
Craft & Handicraft \\
Mode & Fashion \\
Music & Music \\
Publishing & Publishing \\
Interactive Game & Application and Game Developer \\
Technology and Information & \\
Advertising & Advertising \\
Research and Development & \\
Fine Arts & Fine Arts \\
Performing Arts & Performing Arts \\
Television dan Radio & Television dan Radio \\
\hline
\end{tabular}

source: Report of Analysis of Classification of the Creative Economy Activity in KBLI (Classification Book of Indonesian Business Field) 2015

"The creative economy era should be the backbone of the Indonesian economy." The statement was conveyed by Joko Widodo in the opening ceremony of "National Creative Summit," on August 4, 2015 (Issetiabudi, 2019). The ground of the statement was the annual increment in GDP. As stated by the chairman of Indonesia Trade Room (KADIN) in the National Dialogue of Creative Economy, on November 7, 2019, while in 2018 the value of GDP contributed was Rp1.105 billions, it was predicted to be Rp1.200 billion in 2019 (Lestari, Daurina., Rachman, 2019). Unsurprisingly, on December 31, 2018, President Joko Widodo, enacted Presidential Regulation Number 142, 2018, concerning the Fundamental Plan of the National Creative Economy Development of the Period of 
2018-2025. The Presidential Regulation considers that for raising national competitiveness and the Creative Economy contribution to the national economy, a long-term strategic framework on National Creative Economy that function as the integrated and collaborative guidance for Central and Local Government is required. As a result, the issues regarding the creative economy becomes not only the responsibility of the central but also the local government.

Kendal Regency was chosen as one of the 100 epitomai of smart city/regency by the Ministry of Communication and Information (Office of Communication and Information-Government of Kendal Regency, 2018). Six priorities are being developed in Kendal Regency, namely smart living, smart economy, smart branding, smart governance, smart environment, and smart society. The priority programs of smart branding in Kendal Regency are as follows:

1. Establishing and marketing tourism ecosystem (tourism branding)

2. Establishing platforms and marketing local business ecosystem (business branding)

3. Establishing and marketing city appearance (city appearance branding)

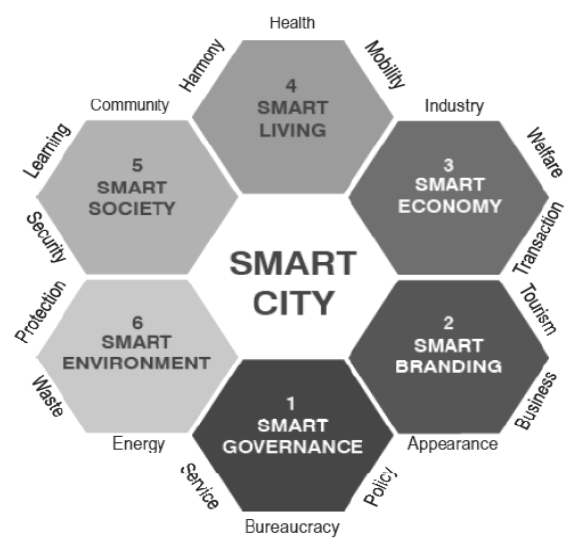

Figure 1. Elements of Smart City in Kendal Regency (source: Government of Kendal Regency, Office of Communication and Information, 2018)

The definition of smart branding in Kendal Regency's Smart City is similar to the city branding concept. City branding is a physical and social attribution regarding the character of a region so that the city owns a particular uniqueness compared to other cities. Therefore, when the city is mentioned, there appears a perception of a particular attribute related to the city's character. Many factors form city branding, ranging from the geographical condition, value, culture and historical artifacts, society, political policy, physical planning, to economy (Karvelyte \& Chiu, 2011). However, as regards city branding for creating the identity of the city as attribution, a field that can be an essential consideration is the creative economy of the region since the creative economy can be considered an identity economy. The reason is the marketization process of a productive society. The production of a creative economy sector is capable of producing meaning, and meaning here means identity (Herrmann-Pillath, 2008). Take Palembang City; in 2019, the city was honored by the Creative Economy Agency as a culinary city due to the diversity of the unique culinary. To that end, the understanding of the creative economy is vital for the local government officials when city branding is planned.

The creative economy concept has been recognized since 2001 in the United States, and it was popularized by John Howkins, who is widely known as the father of the creative economy. In Indonesia, although the concept of the creative economy has been introduced widely since 2007, the concept still generates questions out of the nature that is "new' or "foreign." A new thing should not always be a novelty. What is considered foreign and unfamiliar can be deemed new too. The diffusion theory explains a new concept as innovation. Innovation is an idea, practice, or object that is perceived new by other humans (adoption unit) (Rogers, 2003). The creative economy concept has been known in Europe since 1991, while in the United States, it was just started in 1997 despite being popular in 2001. In Indonesia, it started to be popular in 2007. Nevertheless, this concept is still relatively strange for some people, societal groups, or other adoption units.

The next concept in the diffusion theory is diffusion itself. Diffusion is a process of innovation that is transmitted through many channels in a particular period and a particular social 
system (Rogers, 2003). In general, innovation diffusion consists of four main elements. The four elements are (1) innovation, (2) communicated through a communication channel, (3) in a particular time, (4) into a member of a social system.

Novelty itself has relative definitions. Generally, many define a novelty as a notion that is genuinely used for the first time. In this theory, a novelty is defined as an individual reaction while receiving a notion. If the individual thinks the notion is new, it can be defined as an innovation. A novelty in innovation is not only involved seemingly a new knowledge but also an attitude towards the novelty (Rogers, 2003). Someone may know an innovation but may not have attracted and disliked or not attracted to it, and let alone from agreeing or disagreeing. A novelty in innovation can be expressed into knowledge, persuasion, or decision not to adopt.

OPD's understanding of the concept of a creative economy cannot be judged from how far someone accepts/rejects an innovation. OPD as Government Employees cannot reject an instruction. OPD's understanding should be seen from how far mutual understanding and agreement towards the concept of creative economy applies. Mutual understanding is not a singular understanding. This is the reason for which it cannot be said that someone would immediately understand a concept with merely a one-time study or presentation. A classic problem in the implementation of a governmental program is a lack of understanding of policy or concept by the related institution. Government agencies need to change style and the communication model they use. (Rasyid et.al, 2019). For example, as stated by Kriyantono (2019), the incapability of the government's public relation in coping with crisis stems from the lack of understanding in interpreting the meaning of crisis.

At least, there are four possible kinds of mutual understanding and agreement (McLeod \& Chafee, in ( Rogers \& Kincaid, 1981):

1. Mutual understanding followed by an agreement

2. Mutual understanding followed by a disagreement

3. Mutual misunderstanding followed by an agreement

4. Mutual misunderstanding followed by a disagreement

Understanding and agreement towards a certain issue in this context are about the concept of the creative economy, which is affected by, immediately or not, pluralistic ignorance and knowledge in the network, Pluralistic ignorance is the individual degree in perceiving action or behavior of other falsely (Rogers \& Kincaid, 1981). Pluralistic ignorance and pluralistic knowledge is the indicator of knowledge of individual towards other individual behaviors in the system.

Initially, This research was a part of the research series of Mapping and Clustering of the Creative Economy Subsector in Kendal regency. The first aim was to provide initial data for the government of the Kendal Regency. The initial data was intended to assist the government of the Kendal Regency to develop the creative economy in Kendal regency. However, the researcher found a new result to the Local Government Agencies (OPD) on the creative economy. The mentioned result will be presented by using the diffusion theory. This present research aims to describe the understanding of related stakeholders and the importance of the understanding of the concept of the creative economy to enhance the identity of Kendal Regency.

\section{METHODS}

This qualitative descriptive research is practical since the result would be inputs and initial data for the Agency on Planning, Research, and Development of Kendal Regency. Data regarding the creative economy in the institution mentioned was limited and disorganized. This research, which was a research series of Mapping and Clustering of the Creative Economy Subsector in Kendal Regency, used interviews and FGD as the primary data, and literature review and data of the actors of the creative economy in 2017 from the Department of Youth, Sport, and Tourism of Kendal Regency as the secondary data (the more recent data was not available). Data comprises biodata of 229 actors of small-micro-businesses that are classified as the creative economy, which were spread in 16 districts of 20 of Kendal Regency. The data were collected from May to August 2019.

Afterward, the data were clustered. Data clustering is a process to group data into several groups so that data in a particular group own a high level of similarity and low level of dissimilarity (Tan, Pan-Ning; Steinbach, Michael; \& Kumar, 2006). A cluster here can either mean geographically or in terms of the type of related industry/business. As explained by Sunaryanto (2010) regarding the definition of a cluster, a cluster is a concentration of related companies which are partnered (such as supplier of goods and service, industry, and other supporting institution and other supporters) geographically (Supriyanto et al., 2017). Therefore, data were grouped into the creative economy 
subsector and the regional spread in the clusterization stage. The guidance of the clusterization of the creative economy subsector was based on the Analysis of Classification of the Creative Economy Activity in KBLI (Fundamnetal Book of Indonesian Business Field) 2015. Data that were classified, then, interpreted qualitatively by associating it with the concept of understanding of 'new notion' in the diffusion innovation theory.

\section{RESULT AND DISCUSSION}

\section{Misunderstanding of the concept of the creative economy}

In general, the diffusion of innovation is composed of four main elements. The four elements were (1) Innovation, (2) diffusion of information that is communicated through communication channels, (3) in a particular time, (4) into members of a social system. Referring to the definition of innovation in the theory of diffusion of innovation, the concept of the creative economy is an innovation, namely ideas, practices, or objects considered new by other humans (adoption unit). Although the concept of the creative economy has been applied in many regions of Indonesia, and other countries, for some adoption units, which in this case is Kendal Regency, the concepts are new. The reason is the lack of knowledge concerning the concept of the creative economy. As a result, any unfamiliar ideas for those groups will be seen as an innovation. On the other hand, diffusion is a pattern of information spread and understanding in a particular environment, which, in this case, is the Government of Kendal Regency, primarily in the Department of Youth, Sports, and Tourism. Diffusion is a process of communicated innovation through multifarious channels in a certain period in a societal system (Rogers, 2003). A communication channel here refers to the method of the government of Kendal Regency in delegating data collection activity concerning the creative economy, typically in the form of interpersonal or group via governmental meetings.

Terminologically, novelty is manifold. In general, some people consider novelty as new notions that are genuinely new and first used. According to this theory, novelty is defined as the reaction of an individual when he receives knowledge. If the individual considers the notion as a new thing, the thing would be granted name novelty. The novelty in innovation is involved not only new knowledge but also the attitude towards the novelty (Rogers, 2003). An adoption unit may know about innovation, but it may be that they do not yet have fondness or attraction towards the concept nor hostility, let alone agreeing and disagreeing. The novelty in innovation can be expressed into knowledge, persuasion, or decision not to adopt.

Furthermore, this research will discuss the categorization of innovator users. Roger (2003) and some other communication scholars identify five categories of innovation users, namely innovator, early adopter, early majority, late majority, and laggards. Regarding the innovator, it is a group of people that dare and are ready to try new concepts. Their social relations tend to be more close-knit compared to other societal groups. These people are flexible in creating effective communication, even if a geographical distance exists. Typically, they have a dynamic life and multiple friends or relations of cities. The second group is the early adopter. This group is more local than the innovator. This category produces more opinions than other categories without refraining from searching for information on innovation. People in this category are highly respected and revered owing to their success and passion for trying innovations.

The early majority is the third group, and people in this category do not want to be the first group that adopts innovation. Conversely, they compromise cautiously before deciding to adopt an innovation even in a very long time. These people are essential in legitimating an innovation to show to all communities that innovation is worth to try or relatively beneficial. Next is the late majority. This group is careful regarding the function of innovation. They wait until many people have tried and adopted the innovation before deciding. Sometimes, peer-pressure and economic issues motivated them to do so.

Finally, laggard is the last group that adopts an innovation. They are traditional and reluctant to try new concepts. Typically, this group prefers to have a relationship with people that share similar thoughts. When laggards have adopted new innovation, many people have adopted other innovations and regard them as old-fashioned.

Based on the classification of the adopters above, Kendal Regency can be considered late majority and not laggards. This is because the Local Government Agencies (OPD), such as the Department of 
Youth, Sports, and Tourism, as the executor, carried out the data collection regarding the creative economy out of peer pressure (the government of Kendal Regency), and not from their initiative, making many concepts improper in the data collection process.

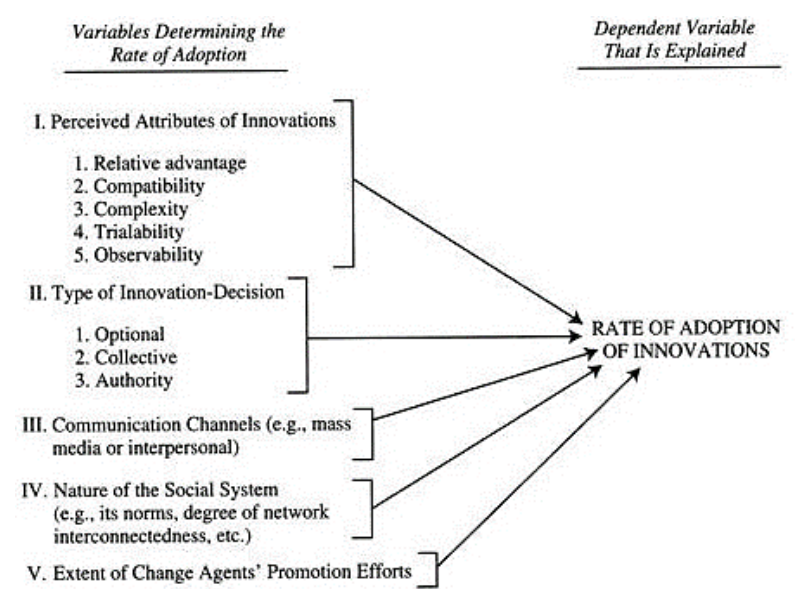

Figure 2. Variable of Rate of Adoption (Rogers, 2003)

The rate of adoption is the relative speed of innovation to be adopted by a member of a societal system. Commonly, it is gauged from the number of individuals that adopt new notions in a certain period (Rogers, 2003). The perceived attribute or characteristic of innovation accepted by the adoption unit is an essential part to explain the rate of adoption. Around 49-97\% from the level of adoption is explained by five attributes that are joint in perceived attributes; those are relative advantages, compatibility, complexity, trialability, and observability. The relative advantage is the degree of innovation accepted and perceived by the adoption unit as a more useful notion than the existing notion. This relative advantage is measured by economic advantage, status effects, and incentive effect. The compatibility is divided into some types, namely suitability of value with belief and previous notions. The complexity need is the level of difficulty of innovation to understand and apply. Trialability is the degree of innovation to apply on a limited basis. Trialability affects the level of adoption significantly, and the adoption unit that initially anticipates innovation, such as laggards, can reconsider their choice and adopt through this trialability. Finally, observability is the degree of visibility from the perspective of other individuals. Innovation is more natural to explain through observation than words.

The understanding of OPD in the Department of Youth, Sports, and Tourism of Kendal Regency lacked the concept of the creative economy because of the variable the perceived attribute had a quite high level of complexity. Complexity is the level of innovation to understand and apply. It caused the implementation of OPD in the Department of Youth, Sports, and Tourism of Kendal Regency in clustering the creative economy to be problematic. In the diffusion process, at least there are four possibilities of mutual understanding and agreement, namely:

1. Mutual understanding followed by an agreement

2. Mutual understanding followed by a disagreement

3. Mutual misunderstanding followed by an agreement

4. Mutual misunderstanding followed by a disagreement

Understanding and agreement towards a particular issue in this research are about the creative economy concept as 'innovation,' which is immediately or not affected by pluralistic ignorance and pluralistic knowledge in the network. The pluralistic ignorance is the degree of an individual in perceiving actions or behaviors other people falsely (Rogers \& Kincaid, 1981). Pluralistic ignorance and pluralistic knowledge are indicators of individual knowledge concerning other individual behaviors in the system. It is assumed that an individual will have lower pluralistic ignorance if she has a strong relationship with other individuals in the system.

In the gradual process of diffusion, there is a possibility of being a 'non-adoption' toward the concept of the creative economy. It happens not because of the less or absence of involvement towards a new notion. According to Yapa (1977), a non-diffusion cannot be likened with a passive condition, not adopting because of the low awareness or indifference. It can be engendered by social, 
cultural, and economic contexts. The diffusion process is a continuous process that continually takes place between actors, institutions, and related industries of the creative economy (Kong, Gibson, Khoo, \& Semple, 2006). In the case of the understanding of OPD in the Department of Youth, Sports, and Tourism of Kendal Regency, it was caused by multi-interpreted text. This was the factor that made the pluralistic ignorance in the form of pluralistic misunderstanding and agreement in the diffusion process of the creative economy in the OPD in the Department of Youth, Sports, and Tourism of Kendal Regency.

KLBI frame can be said imperfect in describing 16 sectors of the creative economy. KBLI, structurally, is a classification of the type of economic activity arranged based on the conceptual framework of production activities. Afterward, the production unit is grouped in detail into industries that have similar economic activities. The activity with the same process and uses of technology in the production process of goods and services will be grouped into one code of KBLI. There is a possibility that the KBLI code has not reflected the real activity of the creative economy. This is because in KBLI there is no robust distinction between creative and non-creative economic activities. Consequently, some KBLI may be included in more than one creative economy subsector. Therefore, the circumspection process and rational perspective are required by the readers (Lien. et al. (eds.), 2016).

\section{The Overlap between the 'Traditional Economy' and the 'Creative Economy'}

The clusterization was performed based on two categories, namely (1) creative economy subsector, and (2) concentration of business spread. Although the data might be categorized into other categories, such as the amount of revenue and capital and the number of business permits, many data listed seemed suspicious as if the informants merely filled the forms. For example, many firms that had run for decades had an imbalance comparison of the revenue and capital, practically making them experience loss for years. Another example is the revenue that was incompatible with the type of business (the monthly revenue only hit hundreds of thousands rupiahs).

Table 2. Clasterization of the Creative Economy Subsector of Kendal Regency in 2017, the Version of the Department of Youth, Sports, and Tourism

\begin{tabular}{lc}
\hline \multicolumn{1}{c}{ Subsector } & Sum \\
\hline Visual Communication Design & 1 \\
Product Design & 8 \\
Interior Design & 1 \\
Fashion & 17 \\
Film, Video, and Animation & 1 \\
Photography & 6 \\
Handicraft & 40 \\
Culinary & 126 \\
Music & 2 \\
Publishing and Printing & 5 \\
Salon & 15 \\
Performing Arts & Total \\
\hline
\end{tabular}

source: Researchers processed data, 2019

Table 3. Clasterization of the Creative Economy Subsector of Kendal Regency in 2017, Based on 2015 KLBI EKRAF

\begin{tabular}{lc}
\hline \multicolumn{1}{c}{ Subsector } & Sum \\
\hline Product design & 8 \\
Fashion & 2 \\
Film, Video, and Animation & 1 \\
Photography & 6 \\
Handicraft & 24 \\
Culinary & 16 \\
Music & 2 \\
\hline
\end{tabular}




Total $\quad 6$

source: Researchers processed data, 2019

The clusterization in table 3 based on the guidance of the 2015 KLBI creative economy shows 66 small and micro business (UMKM) of the creative economy from 229 small and micro-business of the creative economy of the version of the Department of Youth, Sports, and Tourism of Kendal Regency in table 4 . There was a significant gap in the clusterization between the survey conducted by the Department of Youth, Sports, and Tourism and the guidance of 2015 KLBI EKRAF. The salient difference was in the subsector of culinary, fashion, and handicraft. According to the 'Creative Economy: Development Plant of National Culinary 2015-2019 (Tim Studi \& Kementerian Pariwisata Ekonomi Kreatif, 2015), culinary subsector in the Indonesian creative economy is 'preparatory activity, processing, food and drink product displaying that put creativity, aesthetics, tradition, and/or local wisdom as the cardinal element in improving taste and value of the product, to attract purchasing power and enrich consumer's experience. The definition was formulated on the focus group discussion of the culinary subsector performed by the Ministry of Tourism and Creative Economy on May-June, 2014. The keywords of the culinary subsector are creativity, aesthetics, tradition, and local wisdom.

Creativity means a new idea that can elicit added value towards food and beverage. The creation was poured through recipes, procession methods, and display methods. An outright novelty is not demanded here. A novelty can result from the previous development to raise the sale value and attraction in the market. Turning to aesthetic, it means the appearance of a dish that features beauty element and boost the added value and consumer's appetite, such as displaying a more artistic traditional food. The tradition here is anything that is a part of society that has been performed for a long time concerning the habit of processing and food and drink consumption. Evidence of the tradition is either verbal or written information passed down from generation to generation. The elements of tradition are vital here in preserving Indonesian cultural heritage. Another element that is also essential in the culinary subsector is local wisdom. Local wisdom is the identity rooted in a region. The explanation above reflects that the pressure point of the culinary subsector lies in the value of tradition and local wisdom of dishes as cultural heritage (Tim Studi \& Kementerian Pariwisata Ekonomi Kreatif, 2015).

However, the context of culinary in the creative industry should be underscored since many noncreative culinary businesses originate from the agriculture industry and food and drink industry. Creative culinary businesses are guided to the food and drink service that needs capability and skill in culinary of tasteful display and arrangement. In general, the scope of the culinary subsector in Indonesia is divided into two categories, culinary services, and goods. Culinary service is a supply of food and drinks outside the household, such as restaurant and catering, while culinary good is food and drink process that result in packaged products, like specialty foods. Specialty foods have a more unique value than regular goods. The unique value is sourced from culture and local contents, such as traditional foods and souvenir (Tim Studi dan Kementerian Pariwisata Ekonomi Kreatif, 2015)

The researchers' rationale in eliminating 110 business units from 126 to 16 units in the clusterization of the creative economy of the culinary subsector is that many did not meet the specialty foods criteria above. Based on the data received, classification done by Local Government Agencies in the Department of the Youth, Sports, and Tourism of Kendal Regency (OPD Disporapar) was only culinary products. Data concerning culinary service was also not available. Culinary service meant was catering and restaurant. Data regarding restaurant and catering that will be presented later by the related agency is expected to follow the existing culinary subsector criteria.

The second biggest elimination took place in the fashion clusterization. In the previous clusterization, which was performed by the Department of Youth, Sports, and Tourism of Kendal Regency, 17 business units of fashion subsectors were listed. However, the clusterization that was done by the researcher, which sticks to the $2015 \mathrm{KBLI}$ creative economy, only found two units. The consideration was the definition of mode ecosystem explained in the development plan of mode 20152019 (Tim Studi \& Kementerian Pariwisata Ekonomi Kreatif, 2015). In the Indonesian creative economy, fashion is defined as "a lifestyle of dressing that reflects identity (Lien et al. (eds), 2016). Fashion refers to dress, accessories, and footwear.

The substance of fashion subsector in the Indonesian creative economy can be divided into four:

- Type of the process and volume 
- Type of the product

- The function of the product

- Market segmentation

Type of the process and production volumes can be divided into four types, namely (1) mass-scale industry; (2) traditional with manual methods and handmade; (3) made to order, or production process as carried out privately by demand. Made to order itself is divided into two, namely tailor-made, high fashion, and uniform. Afterward, the last categorization based on the type of the process and volume is (4) ready to wear. The process of production is carried out based on the standard/general size. Ready to wear is the most used type compared to the other three. Furthermore, the scope of the fashion functionally can be recognized from the categorization of use, such as casual wear, active sports-wear, formal wear, occasional wear, lingerie, bridal, Muslim wear, and maternity wear (Lien et al. (eds), 2016).

As regards the mode industry, the ecosystem formed is inter-dependence with the related industry (Tim Studi dan Kementerian Pariwisata Ekonomi Kreatif, 20152). The interdependence of each actor affects the creation of artistic value that relies on the surrounding environment to support. Describing it into an ecosystem map, then, there would be four main components, namely (1) creative value chains, (2) consumer market, (3) development environment, and (4) archiving.

A creative value chain is a series of the value creation process that happens due to the involvement of social, cultural, and economic transactions. Each process consists of the main activity, the supporting activity, and the main related actors. In general, the creative value chain is creationproduction-distribution-commercialization. A creative value chain is formed from the old industry that moves the creative industry sector and backward-forward linkage industry in the developing process of the primary industry. (Tim Studi \& Kementerian Pariwisata Ekonomi Kreatif, 2015)2.

Based on the Development Plan of National Mode of 2015-2019, backward-linkage can mean the industry that is supported by the core industry in the fashion subsector, such as the supplier that supports the creation of fashion production while forward linkage is the market that demands to mode industry (core industry). Thus, the primary industry of mode of the creative value chain (creation, production, distribution, and commercialization) and the creation process was in the core industry. The production and distribution process is the backward linkage industry, while commercialization is in the intersection between the forward linkage (the industry that demands) and the core industry.

Against that background, the reason for which 17 business units in the fashion subsector was reduced to two units is that those business units were not the core industry of the fashion subsector. Most of the business units included in the fashion subsector were forward linkage without adding lifestyle value and the identity of the designer.

Another category that was eliminated from the creative economy subsector was 'salon.' Apart from that fact that this was not set in the creative economy subsector since the age of Mari Elka Pangestu and all of the team in the Ministry of the Creative Economy and Tourism that initiated creative economy subsector to the recent creative economy subsector version of the Creative Economy Agency (2018-2019), the salon is a backward linkage industry from the fashion subsector and supporting industry. By far, cosmetics have not been the core industry of the fashion subsector based on the creative economy KLBI nomenclature. The reason is that, according to the Development Plan of Creative Economy of 2015-2019, cosmetic, or salon only provides added value for the fashion show (the core industry of fashion subsector.

The last subsector that was cleared from the clusterization carried out by the Department of Youth, Sports, and Tourism of Kendal Regency was publishing and printing. This is because the clusterization of publishing and printing was incompatible with the clusterization in the 2015 Creative Economy KBLI. The data collection carried out by the Department of Youth, Sports, and Tourism of Kendal Regency grouped photocopy service and printing as the subsector publishing while publishing that is meant by the creative economy subsector is the content creation and spread notion (in terms of audio, pictures, online, offline) that have specific values. As defined by the 2015 Creative Economy KBLI,

A business or imagination and information management activity to create creative content that has a certain uniqueness, that is channeled into text, pictures, and/or audio or the combination, and produced to public consumption, through print, electronic, or online media to earn higher economic, social, and art and cultural values (Lien et al., 2016).

Photocopy and printing business does intersect with the subsector of publishing, but it is only a supporting industry and not part of the subsector. Through reduction and elimination data that was 
carried out by the Department of Youth, Sports, and Tourism of Kendal Regency regarding clusterization of the creative economy subsector, there was misconception towards a creative economy that overlapped with general traditional or conventional economy activity.

Put simply, differentiation of creative economy lies in the identity and planning and planting of unique value to the related economic activity (which was limited on the 16 subsectors of the Creative Economy Agency, which in the last 2019 returned to Ministry of Creative Economy and Tourism). Without identity and unique value, the creative economy and general economy would be overlap in terms of activity.

\section{City Branding, Clusterization of Creative Economy, and City Identity}

Smart branding is a dimension that is planned to develop in the smart city program of Kendal regency by basing to "Kendal Regency Smart City Masterplan 2018-2028." Smart branding is defined as a local marketing innovation that can enhance the competitiveness of a region through three elements, namely tourism, business, and city appearance. The main aim is to increase the brand value of a region that can burgeon the economic, social, and local and cultural activity for the citizen's well being (Dinas Komunikasi dan Informatika-Pemerintah Kabupaten Kendal, 2018). In the masterplan of the smart city of Kendal Regency 2018-2028, the indicator of smart branding variable concerning the city appearance is (1) establishing architecture value reflecting regional value, and (2) establishing borderline (edge), location marker (landmark), direction/city navigation (signage), road structure (path), and connecting point (node) (Dinas Komunikasi dan Informatika-Pemerintah Kabupaten Kendal, 2018).

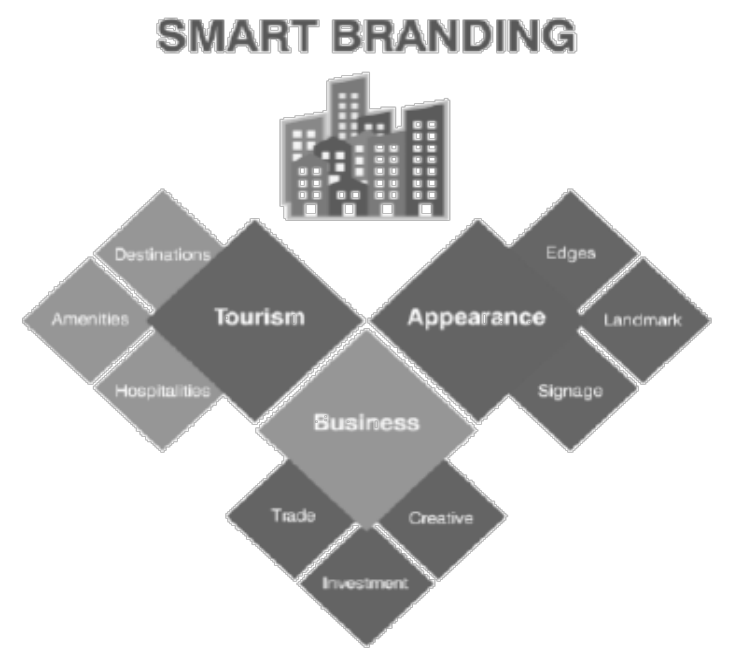

Figure 2. The element of Smart Branding of Kendal Regency

City branding is essential in determining a region to be more positive in terms of economy (Mommas, 2003, in (Karvelyte \& Chiu, 2011)). It is realized from the creating, development, and demonstration of the value of a city through appropriate brand actions, consisting of at least investment element, economic and physical planning, city attraction planning, events, and communication. Furthermore, the planning of city branding should consider various other factors, such as the political aspect of the city, heritage, financial source, geographical location, cultural diversity, social ties (Karvelyte \& Chiu, 2011). As regards the orientation, city branding aims to create an attractive image for tourists and investors and strengthen the identity of the residents (Castillo-Villar, 2018). In short, city branding provides multifarious image and meaning to be ascribed in a city/regency by a particular message. City image, on the other hand, is a set of interpretations of a city/regency that appears spontaneously concerning social and physical stimulus (Luque-Martınez et al., 2007).

The early stage in forming a brand of a region is by creating a concept of brand architecture. Brand architecture is a structured design and management of a portfolio. Many similar 'sub-brands' should be grouped to be the portfolio of the brand. The main challenge is the method of developing a coherent brand umbrella of many activities and audiences that are involved. At the same time, each sector can be communicated in the brand. The targets of audiences can be very diverse, ranging from 
city residents, investors, tourists, to internal stakeholders. The role of policymaker here is to identify a lucid brand attribute regarding the potential owned by the city, as well as the positive perception that is stuck to the various audiences. Questions that says, "what would emerge in your mind when you hear the name of this city? Identification and agreement process regarding city brand attributes needs stakeholder engagement than other elements that are instructive and coercive or up-bottom. Inspiration can stem from anywhere, e.g., in a food culture or city commitment to sustainable environment management (Dinnie, 2011).

The tagline of Kendal Regency is Kendal Permata Pantura dan Kendal Beribadat (Kendal the North Coast's Diamond and Kendal the Religious). Kendal Permata Pantura is a manifestation of the vision of the Kendal Regency to be a prominent region on the north coast of Jave in terms of industry development, entertainment, and accommodation (Azzaki, 2017) for self-sufficiency. Kendal Beribadat, on the other hand, describes a social condition of the people of the Kendal Regency that has numerous religious schools. Based on this tagline, a new question arise, "whether the attributes of the tagline can accommodate various existing audiences? Ranging from city residents, investors, tourists, and internal stakeholders.

The problem of city image is not only about physical development and tourism attraction as planned in the smart branding program of Kendal Regency. Social elements need to be considered. It is this social element that can be a strong-authentic identity and brand attribute. The creative economy is an element of a social economy that needs to be considered in developing the city image. City branding can refer to the extension/development of creative economy activity (Sidauruk \& Saksono, 2018). This is because the creative economy is a manifestation of added value from an idea or notion of intellectual property that contains originality, are born from human intellectual creativity, based on science and technology, skills, and cultural heritage (Perpres Nomor 142 Tahun 2018 tentang Rencana Induk Pengembangan Ekonomi Kreatif). Value, notion, cultural heritage is what makes the identity of each region different and can make the image of the city (city branding).

Table 4. The Work Program of Kendal Regency's Smart City: Smart Branding 2018-2028

\begin{tabular}{|c|c|c|c|c|}
\hline Variable & Indicator & Indicator of RPJM & Program of the Activity & Budget \\
\hline \multirow{3}{*}{ Tourism } & \multirow{3}{*}{ Destination } & \multirow{2}{*}{ Tourism visit growth } & SIMPAR application & 232.000 .000 \\
\hline & & & e-ticketing & 350.000 .000 \\
\hline & & $\begin{array}{c}\text { Number of tourism } \\
\text { destination }\end{array}$ & New recreational mode & 35.122 .378 .000 \\
\hline \multirow{3}{*}{$\begin{array}{l}\text { City } \\
\text { Image }\end{array}$} & $\begin{array}{c}\text { Street Vendor } \\
\text { Arrangement }\end{array}$ & $\begin{array}{c}\text { Arranged street } \\
\text { vendors }\end{array}$ & $\begin{array}{c}\text { Street vendor } \\
\text { arrangement }\end{array}$ & 4.000 .000 .000 \\
\hline & \multirow[b]{2}{*}{ Landmark } & Borderline (Edge) & unspecified & unspecified \\
\hline & & $\begin{array}{c}\text { City Navigation } \\
\text { (Signage) }\end{array}$ & unspecified & unspecified \\
\hline \multirow{3}{*}{ Business } & \multirow{3}{*}{$\begin{array}{l}\text { Easy and } \\
\text { Effective } \\
\text { Investment }\end{array}$} & Application & $\begin{array}{c}\text { DIANTER (Digital } \\
\text { Pelayanan Terpadu)- } \\
\text { Online permit }\end{array}$ & 80.000 .000 \\
\hline & & $\begin{array}{l}\text { Conducive dan } \\
\text { flexible }\end{array}$ & unspecified & unspecified \\
\hline & & Creative Industry & unspecified & unspecified \\
\hline
\end{tabular}

Source: The Masterplan Book 3 of Smart City in Kendal Regency 2018-2028

Table 3 has shown that the importance of the creative economy for developing the branding of the Kendal Regency. Unfortunately, in smart branding, detail on the program and budget of the creative economy is not found. It demonstrated that understanding regarding the creative industry, ranging from the planning in the higher level to the related field executor, was still low. Referring to the variable of smart branding development of the Kendal Regency that consists of tourism, city image, and business, the creative economy can be included in those three variables. The reason is that the creative economy can be the identity of the city. The identity of the city is the core of Kendal Regency's smart branding. Based on the data collected, $98 \%$ of the actors of the creative economy were small and micro businesses and the residents. The anatomy of city/place branding that plays a significant role is the whole image of the identity of the city. The identity of the city consists of 
tangible heritage, value, and society or community that live within it as the unique value of the region (Nursanty, 2019). The consideration towards activity and business that are performed by the resident will create an authentic sphere of experience; one of them is the creative economy.

One of the ways to develop a strong attribute through the creative economy is by a robust creative economy approach as the foundation. The method of clusterization can be the option. The cluster approach can ease the public policy strategy in intervening since there is a specific concentration in a particular point area, called geographical foci (Chapain \& Comunian, 2009). When centering on a particular geographical point, the creation of character or identity would be more comfortable. This is because the production process of food or service also reflects market intrusion towards the production of meaning in society. Principally, any economic activity involves the creation and preservation of identity (Herrmann-Pillath, 2008). This cluster development is similar to One Village One Product (OVOP). It is an approach to develop the potential of a region to create a global product that is unique and regional by exhausting local resources. OVOP approach can be used to enhance the quality of the product of small and micro business and reduce poverty (Badrudin, 2012 in (Supriyanto \& Rozaq, 2017)). This concept has been incorporated into the smart economy program. Besides, other programs can bolster the city branding of Kendal Regency as in the Small and Micro Business corner (pojok UMKM) in 11 priority program of Kendal Regency's Smart Program, which is a part of the group "People Economy." The Program for Developing Young Entrepreneur and technopreneur in the smart city, as well as the program of smart community on smart society, can be developed further into creative communities data collection. In the 2018-2028 masterplan of Kendal Regency's Smart City, some program that strongly supports the creation of city branding in Kendal Regency has been found. However, disintegrations on the planning, as appeared above, seems juggling, and each element seems disconnected. Therefore, the government of Kendal Regency needs deeper and comprehensive understanding concerning the creative economy, from higher to lower level of administration.

\section{CONCLUSION}

Different from the traditional economy, the creative economy is inseparable from the environment of the regency/city and political and economic picture (Davis, Creutzberg, \& Arthurs, 2014). This is because the creative economy produced symbolic values that can trigger the creation of city branding (He \& Gebhardt, 2013). Hopefully, this research can be input for the related Local Government Agencies (OPD), namely Agency for Planning, Research, and Development of Kendal Regency, and the Department of Youth, Sports, and Tourism in collecting data regarding the creative economy. Since Kendal Regency planning to smart city support smart branding as the derivation, the understanding of the concept of the creative economy needs to be deepened. The data collection can be done by collaborating with the related creative economy unit, such as the Ministry of Creative Economy and Tourism, or with nongovernment organization, such as ICCN (Indonesia Creative Cities Network) and importantly Cental Agency on statistic (BPS) so that the data collection can be performed holistically.

\section{REFERENCES}

Azzaki, Adha. (2017). "Perancangan Visual Branding Kabupaten Kendal dan Aplikasinya dalam Media Promosi”. Skripsi: Universitas Negeri Semarang

Castillo-Villar, Fernando Rey. (2018). City Branding and Theory of Social Representation. Bitacora Urbano/Territorial, 28(1): 33-38

Chapain, Caroline., \& Comunian, Roberta. (2009). Enabling and Inhibiting the Creative Economy: The Role of the Local and Regional Dimensions in England. Regional Studies, 44(6), 717734

Davis, C.H., Creutzberg T., Arthurs, D. (2009). Applying an innovation cluster framework to a creative industry:The case of screen-based media in Ontario, Innovation: Management, Policy \& Practice: Innovation Policy in the Creative Industries, 11(2), pp. 201-214.

Dinas Komunikasi dan Informatika Pemerintah Kabupaten Kendal. (2018). Masterplan Smart City Kabupaten Kendal: Buku 2. 
Dinnie, Keith. (2011). City Branding, Theory and Cases. London, UK: Palgrave MacMillan

Rasyid, E., Partini, P., Haryadi, F., \& Zulfikar, A. (2019). Jaringan komunikasi dalam pengelolaan perencanaan program penanggulangan kemiskinan di Provinsi Sulawesi Barat. Jurnal Kajian Komunikasi, 7(2), 133-144. doi: http://dx.doi.org/10.24198/jkk.v7i2.19574

He, J. L., \& Gebhardt, H. (2014). Space of creative industries: a case study of spatial characteristics of creative clusters in Shanghai. European planning studies, 22(11), 2351-2368.

Herrmann-Pillath, Carsten. (2008). "Identity Economics and the Creative Economy, Old and New." Cultural Science Journal, 1(1), 1-15.

Issetiabudi, David Eka. (2019). Menunggu Ekonomi Kreatif Jadi Tulang Punggung Indonesia in (https://ekonomi.bisnis.com/read/20190926/12/1152705/menunggu-ekonomi-kreatif-jaditulang-punggung-indonesia)

Karvelyte, Kristina., \& Chiu, Jui.-Hui. (2011). Planning process of city brands: A case study of Taipei City. Place Branding and Public Diplomacy, 7(4), 257-270

Kong, Lily., Gibson, Chris., Khoo, Louisa-May., \& Semple, Anne-Louise. (2006). Knowledges of the creative economy: Towards a relational geography of diffusion and adaptation in Asia. Asia pacific viewpoint, 47(2), 173-194.

Kriyantono, Rachmat. (2019). The Implementation of the Regulation of the Minister of Administrative Reform and Bureaucratic Reform No 29/2011 in Crisis Management of Government Public Relations. Komunikator, 11(2), 93-106 doi: http://dx.doi.org/10.18196/jkm.112023

Lestari, Daurina., Rachman, Arrijal. (2019). Ekonomi Kreatif Bakal Jadi Penopang Utama Perekonomian RI in (https://www.vivanews.com/bisnis/inspirasi/17625-ekonomi-kreatifbakal-jadi-penopang-utama-perekonomian-ri?medium=autonext)

Luque-Martínez, T., et al. (2007). "Modeling a city's image: the case of Granada". Cities, 24(5): 335352.

Nursanty, Eko. (2019). "The Anatomy of Place Branding: Relating Place Transformation to Community Identity". Place Branding and Public Diplomacy: 1-17

Pangestu, Mari Elka. (2008). Pengembangan Ekonomi Kreatif Indonesia 2025. Hasil Konvensi Pengembangan Ekonomi Kreatif 2009-2015, Pekan Produk Budaya Indonesia 2008. Jakarta: Departemen Perdagangan Republik Indonesia

Peraturan Presiden Republik Indonesia Nomor 142 Tahun 2018 tentang Rencana Induk Pengembangan Ekonomi Kreatif Nasional Tahun 2018-2025

Permanasari, Dian., Praha, Rizky Deco., Celcius Creative Lab. (2018). Opus Ekonomi Kreatif Outlook 2019. Jakarta: Badan Ekonomi Kreatif

Rogers, Everett, M. (2003). Diffusion of Innovations; Fifth Edition. New York: Simon \& Schuster Publisher

Rogers, Everett. M \& Kincaid, Lawrence D. (1981). Communication Networks: Toward a New Paradigm for Research. London: Free Press

Sidauruk, Rosmawati. (2018). Ekonomi Kreatif sebagai Basis City Branding menuju Kepariwisataan Terintegrasi di Kawasan Danau Toba (Creative Economy As Basis of City Branding Toward Integrated Tourism in Toba Lake Zone). Inovasi, 15(2), 83-104.

Suharni, Lien., Haryanto, Dwi., Sanjaya, Yudhi Agustar (editor). (2016). Laporan Analisis Klasifikasi Aktivitas EKRAF dalam KBLI 2015. Jakarta: Badan Pusat Statistik dan Badan Ekonomi Kreatif

Supriyanto, Aji., Basukianto., Rozaq, Jeffry Alfa. (2017). Klasterisasi UMKM dan Potensi Wilayah Berbasis Peta Sebagai Strategi Pengembangan Ekonomi Daerah. Jurnal Pekommas, 2(2), 143-150.

Tan, Pan-Ning; Steinbach, Michael; \& Kumar, Vipin. (2006). "Introduction to Data Mining, Instructor's Solution Manual". London: Pearson Addison-Wesley

Tim Studi dan Kementerian Pariwisata Ekonomi Kreatif. (2015). Ekonomi Kreatif: Rencana Pengembangan Kuliner Nasional 2015-2019. Jakarta: PT. Republik Solusi

Yau, J., \& Al-Hawamdeh, S. (2001). The Impact of the Internet on Teaching and Practicing Journalism. The Journal of Electronic Publishing, 7(1). doi: http://dx.doi.org/10.3998/3336451.0007.102 